\title{
VALIDITY CONDITIONS OF THE JURIDICAL ACT
}

\author{
P. Tărchilă
}

\section{Petru Tărchilă,}

Faculty of Humanistic and Social Sciences

„AUREL VLAICU” University of Arad, Romania

*Correspondence: Petru Tărchilă, ,AUREL VLAICU”

University of Arad, B-dul Revoluţiei nr. 77, Arad, Romanian

e-mail: ijjs@univagora.ro

\section{Abstract}

The legislative act is the subjects` will to create, modify or extinguish a juridical relation of Civil Law. Hence the fundamental elements of the existence of civil juridical act, namely:

1.the subjects`manifestation of will

1.intention to produce, modify or extinguish civil juridical relations

1.the juridical effects whose induction is aimed by parties

Consent is an essential prerequisite of validity for any juridical act and it is defined as the parties decision to complete the juridical act. The consent must meet the following conditions to acquire legal value and to be considered valid:

1.to be issued by a judicial person

1.the intension of closing a legislative act should be known by all parties;

1.the consent should be clear in terms of obligations and rights resulting from such an act;

1.should not be affected by error vice of consent, mistake, fraud, violence or damage.

Keywords: juridical act, consent, mistake, fraud, violence, damage.

\section{Introduction}

Along the ability of any natural and legal entity to contract, which is a prerequisite for the validity of a civil juridical act, the parties' consent to close the 
juridical act is also of great importance. Parties should assume the legal consequences that it produces ${ }^{1}$.

\section{The Provisions of the New Civil Code on the vice of consent}

The New Civil Code stipulates that the juridical institution of consent provides that consent can be considered vice, when it is subjected to error ${ }^{2}$, closed by means of fraud, violence or damage. Both New and Old Civil Codes refer to the institutions of error, fraud, cunningness and damage as vice of consent committed by natural and legal entities that give their consent to the closure of juridical acts irrespective of these vices.

Lack of vice would cause the subjects` refusal to close the juridical act and the juridical relation that results from provision of rights and obligations arising from the act would not be materialised

\section{1.) Error vice of consent}

Mistake or false representation of reality in the consciousness of one of the parties closing the contract is represented by that vice which determines a party to close a juridical act because it wouldn't have been closed under other circumstances. Error as vice of consent has been handled by the Old Civil Code, too, ${ }^{3}$ and it stipulated that only damage brought to the object of a contract can make it null and void. According to the same code, if error was the object of one of the parties but it didn't have determining effects upon the contract, the juridical act cannot be considered null and void. In the old civil law, the institution of error was classified according to the consequences it produces. Thus, there were three distinctive categories, namely: error obstacle, error vice of consent (also called severe error) and indifferent error. ${ }^{4}$ The New Civil Code analyses the institution of error vice of consent referring to parties closing a juridical act. The Code states that the party which finds itself in an essential error at the moment of closing the act can demand the invalidation of the contract if proven that the other party knew or should have known about the error and its importance in the closure of the act ${ }^{5}$.

The new Civil Code develops and handles the institution of error referring to its main forms ${ }^{6}$. They are common especially in civil jurisprudence and can be classified in: essential error, unpardonable error, assumed error, calculation error and error of communication and transmission.

\footnotetext{
1 See also Petru Tărchilă, Drept civil.Partea generală şi Persoanele,Editura Gutenberg,Arad 2008,pag.272

2 See art. 1206 of the New Civil Code.

3 See the provisions of art.954 of the Old Civil Code.

See Petru Tărchilă ,op.cit.pag.126. see the provisions of art 1207 of the New Civil Code

See the provisions of art 1208 to 1211 of the New Civil Code.
} 


\section{P. Tărchilă}

According to the new provisions of civil law, error is essential when it bears on the nature or object of the contract and when it bears on the identity of the object, on the performance or on one of its qualities or circumstances considered essential by both parties without which the contract would not have been closed.

Unpardonable error is in the new civil law a fact or a circumstance which generates confusion and which could be easily admitted by both contracting parties through reasonable diligence.

Moreover, the New Civil Law stipulates that Error of Law cannot be claimed in cases of accessible and predictable legal provisions. Referring to the institution of assumed error, the new legislation considers it an element, fact or circumstance which presents a certain error risk, which has been assumed by all contracting parties or should have been assumed by them. ${ }^{7}$

Referring to calculation error, the new civil legislation stipulates that calculation error does not make the contract void but it claims its amendment.

Still, when calculation error had as object the quality of services provided by the legal act and the quality was essential for the closure of the contract, thus lack of quality would have led to the rejection of contract closure, the contract can be voided at the request of either parties. Error of communication and transmission applies when the will of one of the parties was misunderstood or the declaration was inaccurately transmitted by means of a third party or distance communication means.

\section{2.) Fraud as Vice of Consent}

The New Civil Code regulates the juridical institution of fraud (or cunningness) stipulating that such vice of consent takes place when one party fraudulently mislead the other party by using false evidence (cunning and deceitful) or a party fraudulently omitted to inform the contracting party about certain circumstances that ought to have been revealed ${ }^{8}$. Thus, fraud is a vice of consent which consists of misleading a person through deceitful (cunning) means in order to determine the party to close a juridical act. Lack of such deceitful means would have undoubtedly led to the rejection of the contract. In other words, fraud is a caused error (not spontaneous as the error itself). The party whose consent was corrupted by fraud can claim the contract as null and void even if the error made is not considered essential. Moreover, the new civil legislation stipulates that a legal act becomes null and void when the fraud is committed by the representative or guarantor for the business of the other party, thus noting that fraud should be proven through evidence and not inferred. Fraud has two structural elements, namely:

7 See Beleiu G.,Drept civil român, introducere în dreptul civil ,Subiectele dreptului civill,Ed.Şansa ,Bucureşti 2010,p. 244.

8 See the provisions of art.1214 of the New Code. 
- a subjective, intentional element represented by the intention of one contracting party to mislead the other party and determine it to close the contract.

- a objective, material element represented by the use of one contracting party of deceptive manufactures created for the purpose of misleading the other party. They can be documents, evidence, exhibits, etc. either fake or intentionally forged with the purpose of convincing the other party to close the contract. If such cunning evidence had not been used, the party whose consent was vice (deceived party) would not have closed the contract.

One fact should be reminded here, namely that the new Civil Code stipulates the cumulative existence of both parties for enforcement of fraud as vice of consent. Material elements cannot be represented by moral constraints and threats. Fraud should fulfil two cumulative conditions to be considered vice of consent by one contracting party:

- to be the essential and determining element of contract closure. Lack of fraud should undoubtedly lead to rejection and refusal of contract closure by the deceived party.

- fraud should emerge from the other contracting party and not from a third party. The deceived party can claim the cancellation of the contract on grounds of its vitiation only if it can prove that the other party has used or has known about the use of deceptive means.

\section{3.) Violence as vice of consent}

The consent of one contracting party can be vice by violence when the person is threatened either physically or patrimonial, so that the person accepted to close a contract which would not have been closed under regular circumstances. The person closes the contract only to avoid an imminent and severe danger.

\section{The structure of violence}

Violence as vice of consent has a complex structure, which contains two distinctive elements:

an exterior element consisting of physical or patrimonial threat upon one of the contracting parties. The threat must be so powerful that the party under such fear would believe that without its consent, the life, health and goods of his close relatives and himself are in jeopardy.

a psychological element turned into a strong feeling of fear for one`s life, physical integrity and goods belonging to him or to close relatives. This strong feeling should determine a person to close a juridical act that otherwise would not have been closed. 


\section{P. Tărchilă}

The legal doctrine has established that violence can be classified in two major categories according to the object of threat or the legitimacy of threat. According to the object of threat, violence can be:

- physical violence, aiming at the physical integrity of a person, its goods and patrimonial values;

- moral violence, threatening the honour and dignity of an individual;

Classified according to legitimacy of threat, violence as vice of consent can be: legitimate or illegitimate, namely just or unjust.

It should be noted that a just threat cannot determine the cancellation of a contract, while an unjust threat can determine its cancellation.

For violence to be considered vice of consent, it should meet three requirements, namely:

1.) -the threat must be so powerful that it would become determining for the closure of the contract, which otherwise would not have been closed;

2.) -the threat should not have a legal ground, namely it should be unjust and illegitimate;

3.) -in bilateral or multilateral legal acts, threat should come from the other contracting party or, if it comes from a third party, the contractor knew or should have known the act of violence performed by the third party.

\section{4.) Damage as vice of consent}

The institution of damage as vice of consent defines the material damage (prejudice) suffered by one of the contracting parties, following the closure of a juridical act. ${ }^{9}$ The New Civil Code refers to the legal institution of damage as vice of consent and stipulates that it is the consequence of value disproportion between two mutual performances. The disproportion exists from the moment the contract is closed. Damage can also exist when an underage child assumes an excessive obligation in relation to the heritage, to the advantages it obtains by closing the contract or to the overall circumstances. The party whose consent has been corrupted by damage can demand the cancellation of the contract or the reduction of its obligations as compensation for the damage - interests it is entitled to. The action for annulment is admitted only if the damages exceed half of the value the service performed by the injured party had at the time the contract was closed. The disproportion should subsist until the registration of the cancelation action.In all cases, the court can maintain the contract valid if the other contracting party offers a reduction or, if the case, an increase of its own obligations. It should be remembered that cancelation and reduction of damage obligations prescribe after 2 years from the date the contract was closed. The following types of contracts 
cannot be cancelled for reasons of damage: random contracts, transactions as well as other contracts stipulated by law.

\section{Conclusions}

Along the ability of any natural and legal entity to contract, which is a prerequisite for the validity of a civil juridical act, the parties` consent to close the juridical act is also of great importance. Parties should assume the legal consequences that it produces.

Consent is an essential prerequisite of validity for any juridical act and it is defined as the parties` decision to complete the juridical act. The consent must meet the following conditions to acquire legal value and to be considered valid:

1.to be issued by a judicial person

1.the intension of closing a legislative act should be known by all parties;

1.the consent should be clear in terms of obligations and rights resulting from such an act;

1.should not be affected by error vice of consent, mistake, fraud, violence or damage.

\section{Bibliography}

Legea nr.287/2009, de promovare a Noului cod civil (publicată în Monitorul Oficial al României nr.511 din 24.07.2009.)

P.Tărchilă ,Drept civil.Partea generală şi Persoanele, Editura, Gutenberg,Arad 2008.

L. Pop ,Tratat de drept civil, Editura Cordial Lex,Cluj,2011.

O.Ungureanu , Drept civil, Introducere, Editura Rosetti,Bucureşti 2009.

G. Beleiu, Drept civil, Editura Şansa, Bucureşti 2010. 